\title{
Tumor pathogenesis of human neurotropic JC virus in the CNS
}

\author{
Gary L Gallia, Jennifer Gordon and Kamel Khalili \\ Center for NeuroVirology and NeuroOncology, Allegheny University of the Health Sciences, Broad and Vine, MS 406, \\ Philadephia, Pennsylvania 19102, USA
}

\begin{abstract}
In the last several years, studies have reported the detection of sequences similar to the polyomavirus, Simian Virus 40 (SV40) in human tumors including choroid plexus papillomas and ependymomas. Taken together with well-established evidence that SV40, as well as the human polyomaviruses JC virus (JCV) and BK virus (BKV), are oncogenic in several animal models, new interest has resurfaced regarding a possible role for these viruses in human tumors. In particular, a strong case can be made for re-evaluating the oncogenic potential of JCV in a neurotropic polyomavirus which is the causative agent of the fatal human demyelinating disease, Progressive Multifocal Leukoencephalopathy (PML). In this review, we discuss the transforming capability of JCV in vitro, JCV's ability to induce neural origin tumors in non-human primates as well as in rodents, and several case reports which suggest a possible role for JCV in tumor pathogenesis in the central nervous system.
\end{abstract}

Keywords: JCV; T-antigen; progressive multifocal leukoencephalopathy; human brain tumors; animal model

JC virus (JCV), like SV40 and BKV polyomaviruses, is a DNA tumor virus which contains a genome of closed, circular, double stranded DNA that is separated into early and late coding sequences by the viral regulatory region. The viral early genes, large and small T-antigen, are transcribed prior to DNA replication, whereas the viral late genes, capsid proteins VP1, VP2 and VP3 as well as the accessory agno protein, are transcribed after DNA replication (Frisque and White, 1992). Approximately $70 \%$ sequence homology is shared between the genomes of JCV and SV40, including the coding regions for large T-antigen, while the greatest differences between the viruses are observed within their non-coding regulatory regions.

JCV is known to co-exist within the human population, as greater than $80 \%$ of adults worldwide exhibit JCV-specific antibodies (Major et al., 1992). JCV is an opportunistic virus which is the causative agent of the subacute disease of the central nervous system (CNS), Progressive Multifocal Leukoencephalopathy (PML). PML is a de-

Correspondence: K Khalili

This work represents equal contribution from first two authors Received 20 January 1998; accepted 21 January 1998 myelinating disease which results from the lytic destruction of oligodendrocytes, the myelin producing cells of the CNS. This fatal CNS disease is usually associated with lymphoproliferative disorders, immunosuppressive conditions, and more recently the acquired immunodeficiency syndrome (Berger and Concha, 1995). PML is characterized by the gradual onset of focal neurologic dysfunction and typically involves the subcortical white matter. The most prevalent presenting neurologic signs and symptoms include visual deficits, neurologic impairment, and motor weakness (Brooks and Walker, 1984; Berger and Concha, 1995).

Histopathologically, PML is characterized by multifocal areas of demyelination, enlarged oligodendroglial nuclei with eosinophilic inclusions, and bizarre enlarged astrocytes with irregularly lobulated hyperchromatic nuclei (Astrom et al., 1958; Richardson, 1970). Foci of demyelination arise as JCV initiates a lytic infection of oligodendrocytes which results in their destruction leading to a paucity of this cell type in the central areas of demyelination. Infected but unlysed oligodendrocytes present at the periphery of the lesions contain nuclei which may be two to threefold larger than normal, strongly basophilic, and contain eosinophilic intranuclear inclusions. These intranuclear 
inclusions have been shown to contain JC viral particles as well as viral DNA and antigen. Bizarre astrocytes observed in PML lesions frequently exhibit mitotic figures and occasionally contain JC viral DNA and viral proteins. These astrocytes have been described as having a malignant appearance and are morphologically reminiscent of a neoplastic process.

Although no conclusive association between JCV and human brain tumors has been made, several cases of patients with concomitant PML and CNS neoplasms have been reported (see Table 1). The first of these was noted by Richardson (1961). In this case, the postmortem exam of a 58year-old man with chronic lymphocytic leukemia and PML incidently revealed an oligodendroglioma. There have also been cases described in which PML was associated with multiple astrocytomas (Castaigne et al., 1974; Sima et al., 1983). Castaigne et al. (1974) described an 18-year-old male who suffered a long lasting immunodeficiency syndrome. Postmortem examination revealed, in addition to PML demyelinating lesions, numerous neoplastic foci of anaplastic astrocytes. Ultrastructural analysis of these foci by electron microscopy demonstrated viral particles in oligodendrocytes, but not in the neoplastic astrocytes. Sima et al. (1983) similarly described a PML patient who also had multiple malignant astrocytomas presumably originating from the PML lesions. Ultrastructural analysis of these lesions demonstrated viral particles in both oligodendrocytes and astrocytes of PML foci, but not in the neoplastic astrocytes. Interestingly, no type of immunodeficiency was revealed in this 68year-old man either clinically or at autopsy.

Gulotta et al. (1992) also reported the concomittant occurance of PML and CNS gliomas. In this case of a 30-year-old HIV-1-negative PML patient, autopsy revealed the presence of gliomatous foci. The authors noted a pleomorphic astrocytoma in the brain and diffuse neoplastic infiltration in the brain stem. In neither of these lesions was JCV detected by in situ hybridization.

In addition to the cases of concomittant PML and cerebral neoplasm, JCV has been associated with human brain tumors in the absence of any PML lesions. Rencic et al. (1996) detected DNA from the JCV non-coding region and T-antigen DNA, RNA, and protein in tumor tissue from an immunocompetent HIV-1 negative patient with an oligoastrocytoma. Moreover, this patient did not clinically or microscopically exhibit any features of PML. Interestingly, Boldorini et al. (1998) report the presence of JCV DNA in the brain of a 9-year-old immunocompetent child with a pleomorphic xanthoastrocytoma (see this issue of the Journal of NeuroVirology). These two cases demonstrate the presence of JCV in human brain tumors of immunocompetent non-PML patients. Although a causal relationship between JCV and the development of human brain tumors may currently be considered speculative, these are nonetheless intriguing findings which raise the question of whether or not JCV is involved in tumor pathogenesis in the CNS.

While evidence for the role of JCV in human CNS neoplasms may not be clear, the oncogenic potential of polyomaviruses, including JCV has been well established in several animal models (see Table 2). In particular, intracerebral inoculation of JC virus into non-human primates, owl and squirrel monkeys, results in the development of astrocytomas 16-24 months after inoculation (London et al., $1978,1983)$. Further analysis of the monkey tumor tissue revealed the expression of the JCV early protein, T-antigen, but virion antigens could not be detected in the animals. With one exception, tissue from JCV-infected monkeys was unable to release virus when grown in cell culture (Major et al., 1992), indicating that primate-origin cells may not be permissive for JCV infection.

In another series of studies, newborn Golden Syrian hamsters were shown to develop a broad

Table 1 Association of PML and JC virus with human CNS neoplasms

\begin{tabular}{|c|c|c|c|}
\hline Brain tumor & Underlying immunosuppressive disease & PML classification & References \\
\hline Oligodendroglioma & chronic lymphocytic leukemia & classical & Richardson, 1961 \\
\hline CNS lymphoma & possible Hodgkin's disease & classical & Davies et al, 1973 \\
\hline Glioma & immunodeficiency syndrome & classical & Castaigne et al, 1974 \\
\hline CNS lymphoma & chronic lymphocytic leukemia & atypical & GiaRusso and Koeppen, 1978 \\
\hline CNS lymphoma & renal transplant patient & classical & Egan et al, 1980 \\
\hline CNS lymphoma & renal transplant patient & classical & Ho et al, 1980 \\
\hline CNS lymphoma & none reported & atypical & Liberski et al, 1982 \\
\hline Astrocytoma & none detected & classical & Sima et al, 1983 \\
\hline CNS lymphoma & Hodgkin's disease & classical & Williamson et al, 1989 \\
\hline Glioma & none reported & classical & Gullotta et al, 1992 \\
\hline Oligoastrocytoma & none detected & none & Rencic et al, 1996 \\
\hline Xanthoastrocytoma & none detected & none & Boldorini et al, 1998 \\
\hline
\end{tabular}


Table 2 JC virus induces neural origin tumors in several animal models*

\begin{tabular}{|c|c|c|}
\hline Species & Tumor type & References \\
\hline Owl and squirrel monkeys & $\begin{array}{c}\text { astrocytoma } \\
\text { glioblastoma multiforme }\end{array}$ & London et al, 1978, 1983 \\
\hline Syrian hamster & $\begin{array}{c}\text { medulloblastoma } \\
\text { astrocytoma } \\
\text { glioblastoma multiforme } \\
\text { primitive neuroectodermal } \\
\text { ependymoma } \\
\text { pineocytoma }\end{array}$ & Walker et al, 1973; ZuRhein, 1983 \\
\hline Rat & neuroectodermal & Ohsumi et al, 1985, 1986 \\
\hline Transgenic mouse* & $\begin{array}{l}\text { CNS dysmyelination } \\
\text { adrenal neuroblastoma } \\
\text { neuroectodermal }\end{array}$ & Small et al, 1986a, 1986b; Franks et al, 1996 \\
\hline
\end{tabular}

*All animal models except transgenic mice were induced by intracerebral inoculation of JC virus. Transgenic mice express the entire gene for the JC viral early protein, T-antigen, under the control of the JC virus promoter.

range of tumors approximately 6 months after inoculation with JCV, the most common of which included medulloblastoma, astrocytoma, glioblastoma, primitive neuroectodermal tumors, and peripheral neuroblastoma (ZuRhein, 1983). Tumors of the central nervous system have been detected in greater than $85 \%$ of newborn hamsters inoculated intracerebrally with JC virus, clearly demonstrating its oncogenic potential in neural origin tissue. Again, as in the primate studies, JCV T-antigen was detected in tumor tissue, but no evidence of viral replication or persistent infection could be detected. Similarly, injection of JCV into the brains of newborn rats induced undifferentiated neuroectodermal origin tumors in the cerebrum of $75 \%$ of the animals (Ohsumi et al., 1985, 1986).

Perhaps some of the most interesting observations on the oncogenicity of JCV have come from studies on several lines of transgenic mice which have been generated containing the entire gene for JCV T-antigen under the control of its own promoter. Since these mice do not contain any viral late genes, the phenotypes observed are solely dependent on the expression of JCV T-antigen. Earlier studies by Small et al. (1986a,b) resulted in T-antigen transgenic mice which developed one of two phenotypes: the appearance of adrenal neuroblastomas, or less frequently, abnormal formation of myelin sheaths in the CNS (dysmyelination). We have recently generated additional mice utilizing the same JCV T-antigen transgene and have established a line of mice which exhibit tumors of primitive neuroectodermal origin (Franks et al., 1996). Two interesting observations can be made from these studies, first that T-antigen in the absence of JC virus and therefore viral replication, can alter myelin formation to induce dysmyelination, and second that JCV T-antigen is able to transform cells and induce tumors of neural origin.

Although there is considerable evidence supporting the oncogenicity of JC virus, the pathomolecular mechanisms responsible for JCV-induced tumors are just beginning to be explored. Evidence for the direct involvement of JCV T-antigen expression in tumor formation has emerged from studies on transgenic mice which have demonstrated that JCV T-antigen is able to induce tumors in vivo. Moreover, like its SV40 counterpart, JCV T-antigen can transform cells in vitro, albeit to a lesser degree (Frisque and White, 1992). Postulated cellular events which may lead to a transformed phenotype include the interaction of JCV T-antigen with specific cellular proteins such as tumor suppressor gene products. JCV T-antigen has been demonstrated to form stable complexes with p53 in Tantigen transformed cells in vitro, as well as in cell lines derived from JCV-inoculated animals (Frisque and White, 1992). Interestingly, JCV and SV40 Tantigens physically interact with the same region of p53 (Staib et al., 1996; Ludlow, 1993). JCV T-antigen has also been demonstrated to bind to other tumor suppressor proteins such as pRb and p107 (Dyson et al., 1989, 1990). Moreover, JCV T-antigen has been shown to interact with these cellular tumor suppressor gene products in tumor tissue derived from transgenic mice expressing JCV T-antigen (Krynska et al., 1997). Although the ability of JCV T-antigen to functionally block the inhibitory effects of these regulatory proteins is yet undescribed, future in vivo studies utilizing JCV T-antigen mutants will address the relevance of these interactions in the pathogenesis of JCV-induced tumors.

In addition to its ability to derange cell cycle regulatory proteins, JCV has also been demonstrated to possess mutagenic activity (Theile and Grabowski, 1990). Additional studies (Neel et al., 1996; Lazutka et al., 1996) indicate that JCV is associated with lymphocytes which contain multiple chromosome-type aberrations. Perhaps more relevant in light of earlier studies indicating that JCV is able to transform primary human fetal glial cells (Mandle et al., 1987) is recent evidence that JCV can induce 
chromosomal damage in these cells (Neel et al., 1996).

Although the oncogenic potential of JCV has certainly been described in animal models, as well as in vitro, the evidence for the involvement of this polyomavirus in human tumor pathogenesis will need further investigation. It is known that brain tumors account for about $2 \%$ of all human cancers and are the most frequent solid tumor in children. Genetic alterations have been proposed as molecular pathogenetic mechanisms that are integral in the induction and development of many tumors, including those of the CNS. Such genetic alterations can lead to derangements in both positive and negative cell cycle regulators, inexorably resulting in uncontrolled cellular proliferation (Dirks and Rutka, 1997). In addition, alterations in growth factors and their receptors, such as the epidermal growth factor receptor (EGFR) have also been implicated in human brain tumor development (Wikstrand et al., 1998, see this issue of the Journal of NeuroVirology). While mutations that result in tumor formation have been known to arise from genetic and environmental causes, evidence sug- gests that viruses are capable of inducing cellular changes through the actions of their reguatory proteins, and therefore may contribute to the development of some human tumors. Recently, SV40 DNA sequences have been detected in human CNS tumors including choroid plexus papillomas and ependymomas (Bergsagel et al., 1992; Lednicky et al., 1995; Martini et al., 1996; Stewart et al., 1998, see this issue of the Journal of NeuroVirology). Although the presence of DNA sequences within tumor tissue does not prove any causal relationships, it is noteworthly in light of the fact that SV40 $\mathrm{T}$-antigen has been shown to induce choroid plexus papillomas in transgenic mice (Brinster et al., 1984). As JCV has been associated with the induction of glial origin tumors in several animal models, it would seem a logical step to further investigate these tumors for the presence of JC viral DNA and gene expression.

Although several earlier reports were unable to detect the presence of JCV DNA sequences or Tantigen in human tumors or cell lines derived from human cerebral neoplasms (Dorries et al., 1987; Kosaka et al., 1980; Greenlee et al., 1978), JCV DNA,

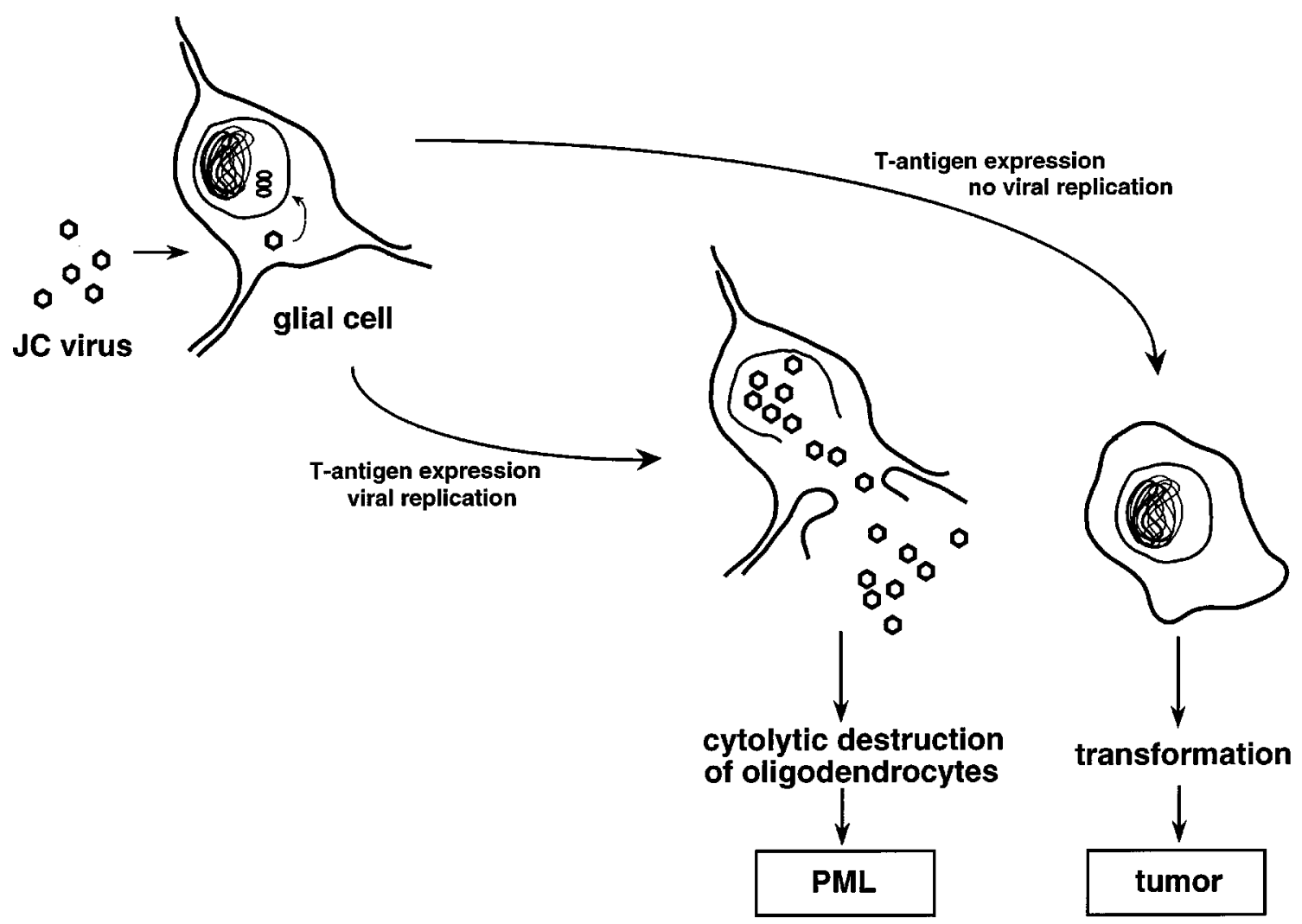

Figure 1. Schematic pathways for induction of the fatal demyelinating disease, PML, by the human neurotropic virus, JCV, and its potential role in the development of CNS glial tumors. During infection with JCV, the viral early protein, T-antigen, orchestrates viral replication and lytic disruption of oligodendrocytes, the myelin-producing cells of the CNS, resulting in foci of demyelination. Alternatively, in the absence of viral replication, expression of the T-antigen may lead to alterations in cell machinery, and ultimately to cellular transformation. 
as well as T-antigen RNA and protein have recently been detected in a human oligoastrocytoma (Rencic et al., 1996). Perhaps the availability of more sensitive techniques will enable a closer examination of cerebral neoplasms for the presence of JCV. Of note, the presence alone of JCV in human brain tumors may not speak to a direct causal relationship for the virus in the development of human tumors. Moreover, as it is becoming clearer that models of human tumorigenesis may involve multiple genetic alterations, the possiblity of a viral contribution in such a scheme provides a more complex and difficult relationship to understand. Thus, the development of more sophisticated animal model systems will enable us to specifically test the impact that JC virus may have on tumor progression.

It is also significant and interesting to note that JCV, unlike its polyomavirus relatives SV40 and $\mathrm{BKV}$, is the etiological agent of the human demyelinating disease, PML. The ability of JCV to induce a demyelinating disease in humans is explained in that, upon infection of oligodendrocytes, JCV T-antigen expression orchestrates events leading to viral replication, virion formation, and subsequent lysis and destruction of the host cell (see Figure 1). Several rounds of productive infection in neighboring cells then result in a growing PML lesion. However, if JCV T-antigen is expressed in a cell in the absence of viral replication, T-antigen may interact with host regulatory proteins to result in cellular transformation, and ultimately uncontrolled proliferation. In addition, JCV may directly induce chromosomal damage which could result in the same end point. In fact, it is possible that the molecular mechanisms underlying the involvement of JCV in cellular transformation is the consequence of multiple cellular effects. The expression of JCV T-antigen,

\section{References}

Astrom K-E, Mancall EL, Richardson EP Jr (1958). Progressive multifocal leukoencephalopathy: a hitherto unrecognized complication of chronic lymphocytic leukemia and lymphoma. Brain 81: 93-111.

Berger JR, Concha M (1995). Progressive multifocal leukoencephalopathy: the evolution of a disease once considered rare. J Neurovirol 1: 5-18.

Bergsagel DJ, Finegold MJ, Butel JS, Kupsky WJ, Garcea RL (1992). DNA sequences similar to those of simian virus 40 in ependymomas and choroid plexus tumors of childhood. New Engl J Med 326: 988-993.

Boldorini R, Caldarelli-Stefano R, Monga G, Zocchi M, Mediati M, Tosoni A, Ferrante P (1998). PCR detection of JC virus DNA in the brain tissue of a 9year-old child with pleomorphic xanthoastrocytoma. $J$ Neurovirol 4: 242-245.

Brinster RL, Chen HY, Messing A, van Dyke T, Levine AJ, Palmiter RD (1984). Transgenic mice harboring SV40 T-antigen genes develop characteristic brain tumors. Cell 37: 367-379. in the absence of viral replication, may result from a non-productive or abortive infection process, with many factors influencing JCV replication, including species or cell type specificity, and even the immune status of the host. Perhaps this is why non-human primate, hamster, and rat models, which are non-permissive hosts for JCV replication, develop CNS tumors but do not exhibit demyelination. Clearly, the ability of T-antigen to transform cells in the absence of viral replication is evident from studies on JCV T-antigen transgenic mice which develop neuroectodermal-origin tumors. Other evidence supporting this pathway in human CNS cells is gleaned from the neuropathological features observed in PML lesions. As noted above, astrocytes interspersed within PML demyelinating foci have been described as morphologically malignant. The general lack of capsids within astrocytes suggests that JCV does not initiate a lytic infection in this cell type. In sum, the findings of JCV in the brains of immunocompetent patients, the neurotropic nature of JCV, and the in vitro and animal evidence demonstrating the transforming ability of JCV invites the re-evaluation of the role that JCV plays in the pathogenesis of human CNA tumors.

\section{Acknowledgements}

The authors would like to thank members of the Center for NeuroVirology and NeuroOncology for their helpful insights and suggestions. GLG is an $\mathrm{MD} / \mathrm{PhD}$ student in the Department of Biochemistry and Molecular Pharmacology at Thomas Jefferson University. JG is a graduate student in the Department of Pathology and Laboratory Medicine at Allegheny University of the Health Sciences. This work was made possible by grants awarded by NIH to KK.

Brooks BR, Walker DL (1984). Progressive multifocal leukoencephalopathy. Neurol Clin 2: 299-333.

Castaigne P, Rondot P, Escourolle R, Ribadeau Dumas JL, Cathala F, Hauw J-J (1974). Progressive multifocal leukoencephalopathy and multiple gliomas. Rev Neurol Paris 130: 379-392.

Davies JA, Hughs JT, Oppenheimer DR (1973). Richardson's disease (progressive multifocal leukoencephalopathy). Q J Med 167: 481-501.

Dirks PB, Rutka JT (1997). Current concepts in neurooncology: the cell cycle - a review. Neurosurgery 40: $1000-1013$.

Dorries K, Loeber G, Meixensberger J (1987). Association of polyomavirus JC, SV40 and BK with human brain tumors. Virology 160: 268-270.

Dyson N, Bernards R, Friend SH, Gooding LR, Hassell JA, Major EO, Pipas JM, van Dyke T, Harlow E (1990). Large $\mathrm{T}$ antigens of many polyomaviruses are able to form complexes with the retinoblastoma protein. $J$ Virol 64: $1353-1356$. 
Dyson N, Buchkovich K, Whyte P, Harlow E (1989). The cellular $107 \mathrm{~K}$ protein that binds to adenovirus E1A also associates with the large T antigens of SV40 and JC virus. Cell 58: 249-255.

Egan JD, Ring Bl, Reding MJ, Wells IC, Shuman RM (1980). Reticulum cell sarcoma and progressive multifocal leukoencephalopathy following renal transplantation. Transplantation 29: 84-86.

Franks RR, Rencic A, Gordon J, Zoltick, PW, Curtis M, Knobler RL, Khalili K (1996). Formation of undifferentiated mesenteric tumors in transgenic mice expressing human neurotrophic polyomavirus early protein. Oncogene 12: 2573-2578.

Frisque RJ, White FA III (1992). The molecular biology of JCV, causative agent of progressive multifocal leukoencephalopathy. In: RP Roos (ed). Molecular Neurovirology. Humana Press: Totowa, NJ. pp. 25-158.

GiaRusso MH, Koeppen AH (1978). Atypical progressive multifocal leukoencephalopathy and primary cerebral malignant lymphoma. J Neurol Sci 35: 391-398.

Greenlee JE, Becker LE, Narayan O, Johnson RT (1978). Failure to demonstrate papovavirus tumor antigen in human cerebral neoplasms. Ann Neurol 3: 479-481.

Gullotta F, Masini T, Scarlato G, Kuchelmeister K (1992). Progressive multifocal leukoencephalopathy and gliomas in a HIV-negative patient. Path Res Pract 188: $964-972$.

Ho K-C, Garancis JC, Paegle RD, Gerber MA, Borkowski WJ (1980). Progressive multifocal leukoencephalopathy and malignant lymphoma of the brain in a patient with immunosuppressive therapy. Acta Neuropathol 52: $81-83$.

Kosaka H, Sano Y, Matsukado Y, Sairenji T, Himuma Y (1980). Failure to detect papovavirus-associated $\mathrm{T}$ antigens in human brain tumor cells by anticomplement immunofluorescence. J Neurosurg 52: 367-370.

Krynska B, Gordon J, Otte J, Franks R, Knobler R, DeLuca A, Giordano A, Khalili K (1997). Role of cell cycle regulators in tumor formation in transgenic mice expressing the human neurotropic virus, JCV, early protein. J Cell Biochem 67: 223-230.

Lazutka JR, Neel JV, Major EO, Dedonyte V, Mierauskine J, Slapsyte G, Kesminiene A (1996). High titres of antibodies to two human polyomaviruses, JCV and $\mathrm{BKV}$, correlate with increased frequency of chromosomal damage in human lymphocytes. Cancer Letters 109: $177-183$.

Lednicky JA, Garcea RL, Bergsagel DJ, Butel JS (1995). Natural Simian Virus 40 strains are present in human choroid plexus and ependymoma tumors. Virology 212: $710-717$.

Liberski PP, Alwasiak J, Wegrzyn Z (1982). Atypical progressive multifocal leukoencephalopathy and primary cerebral lymphoma. Neuropat Pol 20: 413-419.

London WT, Houff SA, Madden DL, Fuccillo DA, Gravell M, Wallen WC, Palmer AE, Sever JL, Padgett BL, Walker DL, ZuRhein GM, Ohashi T (1978). Brain tumors in owl monkeys inoculated with a human polyomavirus (JCV). Science 201: 1246-1249.

London WT, Houff SA, McKeever PE, Wallen WC, Sever JL, Padgett BL, Walker DL (1983). Viral-induced astrocytomas in squirrel monkeys. In: Polyomavaviruses and human neurological diseases. Alan R Liss Inc: New York, pp 227-237.
Ludlow JW (1993). Interactions between SV40 largetumor antigen and the growth suppressor proteins pRB and p53. FASEB J 7: 866-871.

Major EO, Amemiya K, Tornatore CS, Houff SA, Berger JR (1992). Pathogenesis and molecular biology of progressive multifocal leukoencephalopathy, the JC virus-induced demyelinating disease of the human brain. Clin Micro Rev 5: 49-73.

Mandl C, Walker DL, Frisque RJ (1987). Derivation and characterization of POJ cells, transformed human fetal glial cells that retain their permissivity for JC virus. J Virol 61: $755-763$

Martini F, Iaccheri L, Lazzarin L, Carinic P, Corallini A, Gerosa M, Iuzzoline P, Barbanti-Brodano G, Tognon M (1996). SV40 early region and large $\mathrm{T}$ antigen in human brain tumors, peripheral blood cells, and sperm fluids from healthy individuals. Cancer Res 56: $4820-4825$.

Neel JV, Major EO, Awa AA, Glover T, Burgess A, Traub R, Curfman B, Satoh C (1996). Hypothesis: 'Rogue cell'-type chromosomal damage in lymphocytes is associated with infection with the JC human polyoma virus and has implications for oncogenesis. Proc Natl Acad Sci USA 93: 2690-2695.

Ohsumi S, Motoi M, Ogawa K (1986). Induction of undifferentiated tumors by JC virus in the cerebrum of rats. Acta Pathol Jpn 36: 815-825.

Ohsumi S, Ikehara I, Motoi M, Ogawa K, Nagashima K, Yasui K (1985). Induction of undifferentiated brain tumors in rats by a human polyomavirus (JCV). Japan J Cancer Res 76: 429-431.

Rencic A, Gordon J, Otte J, Curtis M, Kovatich A, Zoltick P, Khalili K, Andrews D (1996). Detection of JC virus DNA sequence and expression of the viral oncoprotein, tumor antigen, in brain of immunocompetent patient with oligoastrocytoma. Proc Natl Acad Sci USA 93: $7352-7357$.

Richardson EP Jr (1970). Progressive multifocal leukoencephalopathy. In: Vinken PJ, Bruyn GW (eds). Handbook of Clinical Neurology. Vol 9. Multiple Sclerosis and Other Demyelinating Diseases. Elsevier/North Holland: New York, pp. 486-499.

Richardson EP Jr (1961). Progressive multifocal leukoencephalopathy. New Engl J Med 265: 815-823.

Sima AAF, Finkelstein SD, McLachlan DR (1983). Multiple malignant astrocytomas in a patient with spontaneous progressive multifocal leukoencephalopathy. Ann Neurol 14: 183-188.

Small JA, Scangos GA, Cork L, Jay G, Khoury G (1986a). The early region of human papovavirus JC induces dysmyelination in transgenic mice. Cell 46: 13-18.

Small JA, Khoury G, Jay G, Howley PM, Scangos GA (1986b). Early regions of JC virus and BK virus induce distinct and tissue-specific tumors in transgenic mice. Proc Natl Acad Sci USA 83: 8288-8292.

Staib C, Pesh J, Gerwig R, Gerber J-K, Brehm U, Stangl A, Grummt F (1996). p53 inhibits JC virus DNA replication in vivo and interacts with JC virus large Tantigen. Virology 219: 237-246.

Stewart AR, Lednicky JA, Butel JS (1998). Sequence analyses of human tumor-associated SV40 DNAs and SV40 viral isolates from monkeys and humans. J Neurovirol 4: 182-193 
Theile M, Grabowski G (1990). Mutagenic activity of BKV and JCV in human and other mammalian cells. Arch Virol 113: 221-233.

Walker DL, Padgett BL, ZuRhein GM, Albert AE, Marsh RF (1973). Human papovavirus (JC): induction of brain tumors in hamsters. Science 181: 674-676.

Wikstrand CJ, Reist CJ, Archer GE, Zalutsky MR, Bigner DD (1998). The class III variant of the epidermal growth factor receptor (EGFRvIII): characterization and utilization as an immunotherapeutic target. $J$ Neurovirol 4: $148-158$.
Williamson PJ, Allan NC, McIntyre MA (1989). Cerebral Hodgkin's disease and progressive multifocal leukoencephalopathy. Clin Lab Haemat 11: 281-285.

ZuRhein GM (1983). Studies of JCV-induced nervous system tumors in the Syrian hamster: a review. In: Polyomavaviruses and human neurological diseases. Alan R Liss Inc: New York. pp. 205-221. 